\title{
Factors in taxation policies issuances
}

\author{
Norbertus Purnomolastu \\ Politeknik University of Surabaya, Surabaya, Indonesia
}

Werner R. Murhadi

University of Surabaya, Surabaya, Indonesia

\begin{abstract}
Republic of Indonesia has conducted tax reforms repeatedly through government policies issuance, either by law or government regulations. This research aims to identify factors affecting the government to issue the policies in taxation fields. The factors observed and tested include Government Spending, State Revenue, Debt to GDP Ratio, Income Per Capita, Unemployment Rate, and the President Election as the chance to issuing government policies in taxation fields. This research used the data from the year of 1990-2015 period and those data were processed by logistic regression as its analytical tools. The result of this research showed that factors affecting the issuance of taxation policies by the government is related to the Ratio of State Debt and Income Per Capita, while the Budget Deficit, Unemployment Rate, and Presidential Election factors do not affect the chance of taxation polices issuance.
\end{abstract}

Keywords: taxation police, debt ratio, budget deficit, unemployment rate, presidential elections

\section{INTRODUCTION}

Tax is one of the many sources of a state revenue, but the reality is the compliance of taxpayers is becoming a major problem in various countries, including Indonesia. In 2015 it was noted that the comparison between received tax and the gross domestic revenue or better known as Tax Ratio was still low, just 12\% (Ken 2016). Indonesia government has been issuing policies in tax fields repeatedly as part of the reforms of tax. One of the ways used by the government in taxation was implementing limited tax amnesty in the year 2015 . Limited scale tax amnesty was implemented through the Decree of Finance Ministry of Republic Indonesia which was listed in KMK no 29 and 91 the year 2015, or better known as Reinventing Policy or Sunset Policy II. As the tax revenue is so important to the state revenue, this research would try to analyze factors affecting the government in issuing the policy in taxation fields in form of increasing tax revenues`.

This research is based on the previous research conducted by Bayer et al. (2014) which analyzed the antecedents of tax amnesty policy issuance in United America period of 1981 to 2011. Bayer et al. (2014) predicted the factors which affected the government in issuing tax amnesty policy through some variables, that is, the public expenditure, state revenues, change in public debt, tax burden, amnesty cycle, personal income per capita, unemployement rate, dan presidential election dummy The general result of that research can be summed up that the issuance of tax amnesty policy is affected by the increase of government fiscal needs (Alesina \& Tabellini 1987) and the expectations of taxpayers for the future tax amnesty implementation.

Based on the research conducted by Bayer et al. (2014), this research was extended to focus not only on tax amnesty but also on the government probabilities in taxation policy issuance. The variables used in explaining the factors affecting the government in issuing policies included the State Spending, State Revenue Ratio of Debt to GDP, Income Per Capita, Unemployment Rate, and the Presidential dummies. Theoretically, the increase of the state spending which is done by the reign of President Joko Widodo, affects the government to increase the amount of the tax to finance the infrastructure development projects. However, increasing the tax revenue will have an effect like the decreasing of the people revenue, therefore it 
will bounce back as a low amount of aimed government tax revenues. This thing is taken into the tax policy issuance by the government.

Bayer et al. (2014) stated that the State Spendings and State Revenues will affect the government probabilities in issuing taxation related policy. Limited State Revenues and huge State Spendings will pressure the government to be in budget deficit. To resolve the budget deficit problem, the government should increase the state revenue and reduce the state spending (Almy et al. 2008). In Indonesia, the current government is doing refinement massively in infrastructure sector to chase better economics competitiveness. This massive infrastructure spending will be very useful in improving Indonesia competitiveness in the future, so in order to reduce the budget deficit, suppressing the spending cost is not the wisest choice. Therefore, the government needs to boost the state revenue by giving some incentives to taxpayers to increase the compliance or obedience in tax paying.

Debt Ratio to GDP is also predicted as the factor which will influence the government in issuing policies especially related to tax fields (Favero \& Giavazzi 2007). The optimum or ideal ratio of a state is under $3 \%$. If the ratio is exceeding that psychological number, it means that the government should look for ways to finance their construction development by increasing the tax levy.

People Income Per Capita is predicted to affect the government in issuing taxation policies. If the country is in a crisis, the government can use fiscal policy to resolve the sluggish economy condition by realizing the tax policy.

Unemployment Rate is also predicted in affecting the government possibilities in policy issuance. A high number of unemployment rate will urge the government to give some incentives through tax policy which will stimulate the business work. If the business is working, it is going to create new employment, so it will lower the unemployment rate.

Finally, presidential election dummy is also a predicted factor in affecting the tax policy issuance. In various countries presidential campaigns, the planned economic policy is one of the most observed things from that presidential candidate. The easing tax program from a presidential candidate will be responded nicely by the voters (Gephardt 1985).

Based on the stated explanations above, this research focused on the factors affecting the government in tax policy issuance. This research focused in discussing the effect of the State Spendings, State Revenues, Debt Ratio to GDP, Income per Capita, Unemployment Rate, and the
Presidential Election dummy towards the issuance of government tax policy.

The purpose of this research was to determine the effect of the State Spending Budget deficit (state spending less state revenue), Debt Ratio to GDP, Income per Capita, Unemployment Rate, and Presidential Election dummy towards the issuance of government tax policy. In 2016, the government issued tax amnesty as a fiscal policy to increase the state revenue from tax as a long-term source by upgrading the taxpayer's basic data. The government has been issuing tax policies repeatedly, but there are not many researches conducted to discuss the factors affecting the government in issuing tax policies. Therefore, the result of this study is expected to provide some explanations about the dominant factors that take part in the government decision in issuing tax policy.

\section{RESEARCH METHODS}

The data sources used in this study were secondary data using reports published by the tax office, Central Government Financial Report (LKPP) and Indonesia macroeconomic data source from the World Bank, and the Central Bureau of Statistics. This research used the data from the period of research conducted from 1990-2015.

The dependent variables used in this research were dummy variables in taxation policies in which 0 means the government does not issue tax policies, and 1 when the government issue tax policies. As for the year, the years used were when the government released the tax reform policy and tax relaxation which took place in 1994, 1997, 2000, 2008 and 2015. Independent variables used here were State Budget Deficit (SBD), Debt to GDP Ratio (DR), Income per Capita (IC), Unemployment Rate (UR) and Presidential Election (PE). . State Budget and Revenues were expressed in IDR Trillion and taken from LKPP. The Debt to GDP Ratio was using the percentage of foreign debt to Indonesia's GDP and taken from the world bank. Income per Capita was expressed in people Income per Capita sourced from the World Bank. The Unemployment Rate was expressed in percent and taken from BPS and World Bank. As for Presidential Elections, a dummy variable was used because there was zero or no presidential election occurs, and if in case there was a presidential election.

The analytical technique used was logistic regression by estimating the magnitude of the probability of certain events in a population to determine the probability of events and which factors had a significant effect on the incidence. 
Logistic regression used response / dummy-shaped variable. Logistic regression used dichotomous response variable, in which 1 means the government issues tax policy and 0 for the condition where the government does not issue any tax policy.

\section{RESULTS AND DISCUSSIONS}

This study uses logistic regression model

Table 1. Model Summary

\begin{tabular}{cccc}
\hline Step & $\begin{array}{c}-2 \text { Log } \\
\text { likelihood }\end{array}$ & $\begin{array}{c}\text { Cox \& Snell R } \\
\text { Square }\end{array}$ & $\begin{array}{c}\text { Nagelkerke } \\
\text { R Square }\end{array}$ \\
\hline 1 & $18.724^{\mathrm{a}}$ & .228 & .365 \\
\hline
\end{tabular}

a. Estimation terminated at iteration number 6 because parameter estimates changed by less than .001 .

Tabel 1. Nagelkerke's Square value can be interpreted as the same with $\mathrm{R}^{2}$ towards OLS. It shows that Nagelkerke $=0.228$, which means that variability of dependent variables which can be explained by independent variables is $22.8 \%$.

Classification is used to read prediction accuracy. The SPSS result shows that there were 5 tax policy events in Indonesia, but the prediction of the occurrence of the existing tax policy shows that only 2 events were precisely predicted, so the accuracy rate of $2 / 5=40 \%$. While in 21 events when no tax policy was issued, and it turned out right that there was no tax policy issued in 21 events, so the percentage of accuracy of the model was $100 \%$. Overall, the percentage of model density was $88.5 \%$, where out of 26 events, 23 events were in accordance with the prediction so that the correct percentage is $88.5 \%(23 / 26)$.

Table 2. The Results of Logistic Regression

\begin{tabular}{lccc}
\hline \multicolumn{1}{c}{ Variables } & $\mathrm{B}$ & Sig. & $\operatorname{Exp}(\mathrm{B})$ \\
\hline Budget Deficit (SBD) & 0.014 & 0.292 & 1.015 \\
Debt to GDP Ratio (DR) & 0.102 & $0.05^{* *}$ & 1.107 \\
Income Per Capita (IC) & 0.002 & $0.082^{* * *}$ & 1.002 \\
Unemployment Rate (UR) & -0.552 & 0.139 & 0.576 \\
Presidential Election (PE) & -0.750 & 0.671 & 0.472 \\
\hline
\end{tabular}

Logistic regression can be written as:

$$
\begin{aligned}
\operatorname{Ln}\left[\frac{p}{1-p}\right]=-5,129+0,014 . \mathrm{SBD} .+0,102 . \mathrm{DR} \\
+0,002 . \mathrm{IC}-0,552 . \mathrm{UR}-0,750 . \mathrm{PE}
\end{aligned}
$$

Based on table 2, it can be seen that Budget Deficit and GDP has no significant effect on the possibility of tax policy issuance. This result is different from the hypothesis that there is a positive relationship. A possible explanation for this result is that state revenues other than taxes may also originate from State-Owned (BUMN) dividend payments and nontax state revenues. Huge State expenditures, compared to income from taxes, will lead to budget deficits. However, for the government, it is not easy to raise tax revenue when the economic conditions are experiencing difficulties. Then the alternative to overcome the budget deficit is to make savings in the form of budget cuts from each ministry, followed by non-tax state income and state dividend payments. Interpretation of Odd Budget Deficit = 1.015, it means that every increase of Budget Deficit then odds of the existence of tax policy will rise $1.015 \mathrm{x}$.

The State Debt to GDP Ratio has a significant positive effect on the possibility of issuing policies by the government. The Debt to GDP Ratio is also expected to affect government policy in issuing taxation policies. If the debt to GDP ratio is increasing, then the government should seek ways to reduce debt while maintaining the rhythm of development. Then, the government will increase tax payments by encouraging incentives in taxes (Blanchard \& Leigh. 2013). The odd ratio is of debt / GDP $=1.107$ : meaning that 1 increase in Debt to GDP Ratio it has the power of 1.107 times to increase the prediction of the tax policy.

Income Per Capita has a positive significant effect on the possibility of issuing tax policies by the government. People income increase will encourage the government to intensify and extensify tax revenue by issuing tax policy. Odd income per capita $=1.002$, means any increase in income per capita will increase the odds of the tax policy issuance to rise $1.002 \mathrm{x}$.

Unemployment Rate does not affect the possibility of tax policy issuance by the government. The findings of this study had contradictory results because the unemployment rate is not a factor in Indonesia government's consideration for issuing tax policies. In some countries, the unemployment rate will be very influential, as the unemployment rate increases, the government will tend to issue a major tax relaxation policy to corporates, in the expectation that the corporate will be able to expand the business so that it absorbs workforces (Leonard \& Zeckhauser, 1987). However, this study found that there were no significant effects in Indonesia conditions. Odd Unemployment $=0.576$, which means that every increase of Unemployment then the odds of the tax policy existence will increase $0.576 x$.

Presidential election as dummy has no effect on the possibility of tax policies issuance by the government. One of the most interesting topics in the presidential election is each presidential candidate's economic policy plan. In some developed countries such as the United States, the main economic tax policy issue is interesting to be 
discussed. The presidential candidate who will carry out a tax relaxation policy will tend to get sympathy from the public, which at the time of the chosen, the president is expected to realize the tax relaxation policies. However, this result is not found in this study. This indicates that the issue of tax policies in the presidential election is not a major issue that becomes the focus of public, so whoever is elected president does not significantly affect the tax policy changes. Odd Presidential Election $=0.472$, means that every occurrence of Presidential Election agenda will increase the odds of the existence of tax policy $0.472 x$.

\section{CONCLUSIONS}

The results of this research showed that the factors affecting the issuance of taxation policies by the government are associated with Debt to GDP Ratio and Income Per Capita. While the factors such as Budget Deficit, Unemployment Rate, and Presidential Election do not affect the possibility of issuing tax policy. This research used the logistic model because it did not fulfill the assumption in multiple discriminant analysis, so the weakness of this research was using the logistic model as the analytical tool. Suggestion for the future research is the next researcher can separate the factors of Budget Deficit within as the State Revenue and State Spending Budget..

\section{REFERENCES}

Alesina A. \& Tabellini G. 1987. A Positive Theory of Fiscal Deficits And Government Debt In A Democracy. Working Paper No. 2308. National Bureau of Economic Research 1050 Massachusetts Avenue Cambridge, MA 02138.

Almy R., Dornfest A. \& Keyon D. 2008. Fundamental of Tax Policy. Kansas City Missouri: International Association of Assessing Officers.

Bayer C.R., Oberhofer H. \& Winne H. 2014 The Occurrence of Tax Amnesties: Theory and Evidence. Working Paper No. 2014-06. University of Salzburg

Favero C. \& Giavazzi F. 2007. Debt And The Effects of Fiscal Policy. National Bureau of Economic Research 1050. Massachusetts Avenue Cambridge, MA 02138 . http://www.nber.org/papers/w12822

Gephardt R. 1985. The Economic And Politics Of Tax Reform. Cato Jaurnal 5(Fall): 2.

Ken D. 2016. Manfaat Pengampunan Pajak, Direktur Jenderal Pajak, Bisnis . Jum'at, 18 Maret 2016.

Leonard, H.B. \& Zeckhauser, R.J. 1987. Amnesty, Enforcement, and Tax Policy. Tax Policy and The Economy 1(Summer). 